\title{
Acts, Events, and Stories. On the History of Danto's Compatibilist Narrativism
}

\author{
Thomas Uebel \\ Dept. of Philosophy, University of Manchester, Manchester, UK \\ thomas.uebel@manchester.ac.uk
}

\begin{abstract}
The response given to C.G. Hempel's well-known challenge by Arthur Danto in his Analytical Philosophy of History of 1965 - that deductive-nomological and narrative explanations are logically compatible yet employ incommensurable schemata - is here investigated from a historical perspective. It is shown that the developmental trajectory that emerges from an analysis of Danto's previous writings - including not only a forgotten paper of $195^{8}$ but also his $\mathrm{PhD}$ dissertation of $195^{2}$ - contains distinctive step-changes with publications of 1953 and $195^{6}$ still prior to that of $195^{8-59}$ which enabled his subsequent discovery of narrative sentences. It is also argued that Danto's developmental trajectory runs contrary to that presumed by some prominent commentators. Analytical History of Philosophy was not the midpoint of his ascent from mainstream philosopher of science to high priest of postmodern aesthetics, but represents a reasoned retreat from his early historical idealism.
\end{abstract}

\section{Keywords}

narrative explanation - narrative sentences - historical idealism - Arthur Danto C.G. Hempel - R.G. Collingwood

\section{Introduction}

Arthur Danto's Analytical Philosophy of History $(A P H, 1965)$ is widely recognized to have inaugurated the post-positivist phase of analytical philosophy of history by defending the autonomy of narrative explanations against demands for reduction to nomological explanations. So-called narrative 
sentences - sentences which report an earlier event in terms of later ones and which could not have been recognized as true at the earlier time ("The year 1618 was the beginning of the Thirty Years War") - provided the crucial data by exemplifying, in history, the asymmetry of explanation and prediction. ${ }^{1}$ Since Danto also conceded, however, that both narrative and nomological explanations can be given of historical events, questions have increasingly been asked whether Danto had really plumbed the true depth of the phenomenon he brought to prominence and whether the position he developed made the sharp break with logical positivism's scientism that appeared to be required. ${ }^{2}$

The most critical questions Danto's theory faces spring from the debate about realism and antirealism in history that was prompted by the recognition of the nonrepresentational elements that narratives introduce. ${ }^{3}$ To the question whether historical accounts can be true Danto answered in the affirmative but left open to what extent this applies. Since I propose to investigate the history of Danto's philosophy of history, my conclusions fall within the scope of that debate. Yet for present purposes these metahistorical questions must remain bracketed and, accordingly, I will adopt the language of representationalism. My aim is to deepen the understanding of Danto's theory by considering its prehistory which has not been investigated in any depth before. My argument will be that Danto's theory is misunderstood if it is regarded as often portrayed, for instance, in the introduction and postscript to the 2007 reprinting of Narration and Knowledge (itself a 1985 reprinting of $A P H$ with additional essays $).{ }^{4}$ Rather than offer a half-hearted compromise with the orthodoxy as a halfway house on his journey from positivist philosophy of science to the aesthetics of postmodernism, it constituted Danto's retreat from his youthful historical idealism to a position of reasoned - and much enhanced equilibrium. ${ }^{5}$ Nonrepresentationalists may regard the argumention provided

1 Narrative sentences were first discussed by Danto in the 1962 paper of the same name which then became the central chapter of $A P H$. (Quotations from that paper will give references to both the original and its virtual reprinting in $A P H$; the pagination of the original text of the latter remained identical throughout all reprintings.)

2 See, e.g., Louis Mink's review of $A P H$ (1968) and, following him, numerous essays by Paul Roth, most recently (2017), and, on independent grounds, the writings of Frank Ankersmit, e.g. $(2007 \mathrm{~b} / 2009)$.

3 The number of contributions to the realism debate, especially since Hayden White's Metahistory (1973), is enormous and defeats even a cursory listing.

4 Both the new introduction and postscript, by Lydia Goehr and Frank Ankersmit respectively, have also been published separately, so they are meant to offer authoritative interpretations.

5 While the present paper was under review Paul Roth alerted me to another one protesting the predominance of the postmodernist art critic Danto over previous philosophers of the same name: Earle (2018). Notably, our concerns do not overlap, for my investigation here 
as offering an alternative perspective on Danto's work and are invited to assess its utility.

Narrative sentences apart, the distinctive thesis of $A P H$ is that narratives by themselves can provide an explanation of historical events. Call this Danto's "narrative thesis". It brings with it a certain revaluation of the term "explanation" which is highlighted by what I term his "compatibilist narrativism": the conception of historical explanation as logically compatible but ideologically incommensurable with natural-scientific ones.

Hempelian deductive-nomological explanations and Danto's narrative explanations are compatible in that they can be applied to roughly the same events, but they are incommensurable in that their conceptual allegiances diverge. ${ }^{6}$ The intentional idiom which features in all narrative explanations involving human agents observes a different regime of justification for its claims than the languages of the natural sciences: the making sense of the former does not translate into the testing of the latter. So deductive-nomological and narrative explanations do not explain in the same sense: the laws provided for Hempelian redescriptions of the historical events in question underwrite the singular causal claims made about them (Danto was a Humean about causation), but they do not make the sequence of events intelligible when it is cast in intentional or other everyday terms. Autonomy is granted to narrative explanations for they alone provide the specific linkages between the events mentioned as beginning and end of a story. Narrative explanation is causal, to be sure, but its point lies in isolating as intelligible "in human terms" a particular sequence out of the endless chains of events that make up the causal nexus to which it belongs. ${ }^{7}$

concerns the development of the philosopher of history mainly up to $A P H$, whereas Earle focuses on the epistemologist Danto of the late 196os and 1970s.

6 For Hempel's "covering law" schema of scientific explanation and its application to history see his (1942). Danto did not speak of "incommensurability" in $A P H$ but the term captures well how the compatibility of the two modes of explanation is qualified there. Moreover, not only does this appellation feed off his affinity with Kuhn's revolution in the philosophy of science which Danto repeatedly stressed, e.g., (1985, xi), (1995, 72), (2007a, 226), (2013a, 29), but already early on - and many years before Kuhn's (1962) and his own APH - Danto spoke of different "frames of reference" within which to comprehend historical events as "incommensurable" (1955, 502).

7 Needless to say, much more needs and can be said about this reading of Danto's theory which stresses elements often neglected, but this is not my topic here. For the record, however, 
So how did Danto arrive at the narrative thesis? Note that "Narrative Sentences" (unlike $A P H$ which it preceeded) neither mentioned Hempel's challenge that the nomological underpinnings of historical explanation be made explicit nor did it draw out its consequences for Danto's response. To be sure, Hempel lingers in the background for Danto's introductory paragraph notes that narrative sentences "suggest a differentiating feature of historical knowledge" and that they "help show why the proper answer to the tedious question 'Is history art or science?' is: 'Neither"' (1962, 146/1965a, 143). And after narrative sentences were introduced it is also noted that "[i]t is generally admitted that a scientific theory cannot predict an event under every true description of that event" $(1962,176 / 1965 \mathrm{a}, 177)$. Yet the bearing of narrative sentences on the project of providing nomological explanations in history was not discussed further. Precisely that was the task of $A P H$. Only there Danto confronted the issue that "the sociological fact that narratives are often, and even typically advanced as explanations, and the psychological fact that often, and even typically, we want, and are often satisfied with a true story when we require an explanation, cannot be accepted as fully supporting, without further analysis, the claim" to history's explanatory autonomy $(1965 \mathrm{a}, 203)$. The compatible-but-incommensurable thesis remained to be formulated and properly worked out in $A P H$.

Nevertheless it is clear that the discovery of narrative sentences brought Danto to the threshold of his distinctive philosophy of history. While they do not make it impossible to give $\mathrm{DN}$-explanations of the events mentioned in them (albeit under different descriptions), they do bring out that properly historical explanation is essentially retrospective such that, as noted, the symmetry of nomological explanation and prediction does not apply. But what brought on the discovery of narrative sentences? To see this, his philosophical development must be investigated more closely - which it has not been so far. ${ }^{8}$

let me note that it needs to be critically examined whether Danto was able to sustain the compatibilism he so ingeniously intended. What precisely is the relation between nomological and narrative explanations beyond their extensional equivalence? And what happens to the compatibilist story once Hempel's account of scientific explanation is recognized as "irrelevant" (as Danto did in 1995, 85)? And, finally, what about the tension between realist ambitions for historical explanation and the non-representational elements introduced into it by the use of narratives, a tension recognized by Danto $(1965 \mathrm{a}, 142)$ but never resolved. (In [2017] I argued that, for all his advances, Mink still faced a similar problem, but this does not absolve Danto.) For a little more on the role played in Danto's compatibilism by his Humean view of causation, see Fn. 25 below.

8 NB: "more closely". Unfortunately not all the topics that need be covered by a full investigation of the development of Danto's philosophy of history, especially the role of his teachers Ernest Nagel and John Herman Randall Jr., can be dealt with here (but see Fns. 10 and 28 below). 
Frank Ankersmit once mused that "there is something odd" about $A P H$ as the beginning of Danto's distinguished career: "What analytical philosopher in the 196os would have planned to make his name with a book on so outlandish a topic as philosophy of history?" (2007a, 175) In her "Afterwords: An Introduction to Arthur Danto's Philosophies of History and Art" Lydia Goehr appears to have dug deeper and wrote:

Danto began his professional life in the 1950s as a philosopher of science. He quickly became interested in the influence of the positivist philosophy of science of his day on the philosophy of history. His analytical philosophy of history was written 'out of the spirit' of science and particularly out of the nomological or covering-law model of science that Hempel had begun developing in the 1940s.

2007a, 22/ 2007b, xlviii, orig. emphasis

A little later Goehr wrote: "Danto began as an analytical philosopher of science and over time became an analytical philosopher of art" (2007a, 24/2007b, li). While there is something in these outlines that is undoubtedly correct, they misrepresent the basic dynamics of Danto's development.

Danto did not start out as a philosopher of science who became interested in philosophy of history, indeed, he did not even start out as an analytical philosopher. When he started out in graduate school at Columbia as a former student of the (by now legendary) historian William J. Bossenbrook at Wayne State, Danto had to study lots of history of philosophy but he retained his already acquired leading interest - beyond the practice and theory of art - in philosophy of history. ${ }^{9}$ Danto studied with Ernest Nagel but wrote an MA dissertation on Georges Sorel and after two years away he returned with a newly acquired taste for analytic philosophy to write a dissertation on philosophy of history in $1952 .{ }^{10}$ His first two published papers also concern philosophy of history and contain precious little philosophy of science as such; Hempel's

$9 \quad$ In his "Intellectual Autobiography" Danto noted briefly that while graduating as a history major he "became engaged by the philosophy of history" (2013a, 6). In a virtual interview with Ewa Domańska nearly twenty years earlier Danto recalled doing "a great deal of reading in the philosophy of history" during his undergraduate years, including Spengler, Toynbee, Collingwood (and Marx and Hegel via Sidney Hook); see his (1998, 167). On Bossenbrook's influential teaching, albeit in relation to Hayden White, see Megill (2009).

10 For more on Danto's Columbia experience, his exposure to history of philosophy there and his discovery of analytical philosophy during his first teaching job in Colorado before returning see his (1998a, 176; 1998b; 2013a, 8-12; 2013b, 110). Danto's own recollections and prefatory remarks mention as his Columbia teachers John Herman Randall Jr. (1973, xiii, 1998b), a celebrated historian of philosophy who also published on philosophy of history 
DN-model was not even mentioned in them. Danto adopted philosophy of science as his niche only in the course of the 1950s in the run-up to gaining tenure in 1960 when his philosophy of science anthology, edited with Sidney Morgenbesser, was published.

This developmental dynamic is not made fully explicit but agrees with what Danto tells readers of his "Intellectual Autobiography". Yet the story told there also needs fixing. According to it, Danto "devoted the entire summer" to writing "Narrative Sentences" "after [he] was tenured, in 196o" (2013a, 15-16). The paper was published in Vol. 2 No. 2 of the then new journal History and Theory in 1962. Yet Danto also recalled an advertisement for the journal which listed "the outstanding papers it had published, in which no mention was made of my paper. It was at that point that I realized I would have to write a book on the philosophy of history if my work was to get noticed." And he added: "My sabbatical year, 1961-1962, was dedicated to this labor." (2013a, 16-17) ${ }^{11}$ These dates do not cohere. (The list must have appeared after the publication of his paper which was written before his sabbatical.)

Things become clearer when the "Preface" to the original edition of $A P H$ is consulted which names Danto's sabbatical year, 1961-1962, for the writing of "the bulk" of it (1965a, viii), and when account is taken of the remark (2013a, 20) that he put aside the manuscript in 1962 to work on a book on Nietzsche (1965b). Together with some further remarks, the dates given fit together once we note that there were two stages to the writing of $A P H$. The "Introduction to the Morningside Edition" confirms the writing of "Narrative Sentences" to 1961 and noted that $A P H$ was "drafted the following winter" (1985, xii, emphasis added). Clearly then, the sobering thought that a book on philosophy of history was needed if he wanted "Narrative Sentences" to get noticed must have therefore occurred to Danto not before he started his draft of it in 1961-62, but before he returned to finish his work on it after he completed the Nietzsche book.

Why does this matter? It helps get the story of $A P H$ straight. Danto's unvarnished anecdote suggests that after discovering narrative sentences and publishing a paper about them, he then invented an entire philosophy of history in order to get his idea to a wider readership, but this story is not borne out. Danto's philosophy of history was much longer in the making. Moreover, even

and to whose Festschrift Danto contributed (1968b), and the influential philosopher of science Ernest Nagel (1998a, 167 and 17; 2013a, 8-9 and 12; 2013b, 110). See also Fn. 27 below.

11 Elsewhere too Danto stated that "when the magazine listed some of the important papers it has published as an incentive to subscribe, my piece was not mentioned. At that point I realized it would be lost if I did not publish a book." (2007a, 193) 
more importantly, its $A P H$ version does not represent Danto's breaking out of a positivist confinement he was previously held in but rather, as we shall see, his attainment of a balance between scientific and humanist demands on history that his previous efforts had failed to achieve.

The autobiography notes that his first published philosophy paper "was an effort ... to begin to lay out a sort of logic of narration" (2013a, 12). Well, this very much looks like a narrative sentence. ${ }^{12}$ Readers of "Mere Chronicle and History Proper" (1953) are unlikely to see in Danto's well-argued rejection of W.H. Walsh's distinction between "plain" and "significant narratives" (1951, 31) a critique repeated in $A P H$ - much of a new logic. To be sure, with hindsight we can see on the paper's horizon a thought like that later expressed in $A P H$ at the end of the chapter preceding the radically rewritten version of the 1953 paper (which in turn precedes the virtually unchanged reprinting of "Narrative Sentences"): "The difference between history and science is not that history does and science does not employ organizing schemes which go beyond the given. Both do. The difference has to do with the kind of organizing schemes employed by each. History tells stories." (1965a, 111) Yet that history tells stories was not all emphasized in 1953, in fact, it was taken for granted without much ado. Nor did the original paper conclude, as the chapter with the rewritten argument in $A P H$ does, with the admission that narrativists have to concede an important point to "relativists" (1965a, 142). Instead, the original paper ended with an unqualified invocation of the Rankean ideal: "describe the facts of the past 'wie es eigentlich gewesen ist" (1953, 182).

There was a long way to go towards the "logic of narration", even the recognition that a distinct logic was needed. Thus the claim typical for $A P H$ that "[a] narrative describes and explains at once" $(1965 \mathrm{a}, 141)$ cannot to be found here, only the phrase "to describe causally connected events is to report precisely what happened" $(1953,182)$. Nor did Danto claim the equivalence of description and explanation in narrative in his next paper on philosophy of history, "Historical Questioning" of 1954. This paper rather presents what turned out to be the first of several critical engagements with the historical methodology recommended by philosophers of history which $A P H$ later called "Historical Idealists: Croce, Dilthey, Collingwood, etc.", according to whom "some sort of empathetic apprehension of the inner workings of another mind" or Verstehen

12 I return to whether this appearance is correct in $\S 6$ below. 
was needed $(1965,205)$. By contrast Danto held that "there is nothing mysterious in historical knowledge, nor need we, in order to understand how such knowledge is possible, call into play some special department of the human mind, or some special gift of the talented few." $(1954,97)$ To make his case Danto inveighed against what he called the "Teutonic argument" $(1954,91)$ for a radical separation of history as a science of human actions from the other sciences on account of a categorical, even ontological, difference of its subject matter, history being the one-of-a-kind and uniquely-occurrent. ${ }^{13}$ Danto did not, however, identify the purveyors of the Teutonic Argument as such. ${ }^{14}$

That noted, it could perhaps be said that to date Danto was still occupied with arguing the negative complement to his positive narrativist thesis, but what is very much in question is whether the latter was already clear to him. To be sure, the direction of his thoughts already led away from any straightforward assimilation of history to natural science. "Historians ask specific questions about specific events, not because these events ontologically defy any but historical analysis, but because the historian's needs are intellectually what they are." They ask the particular questions they ask because "as human beings, historians are interested in other human beings in a different way than the way in which they are interested in other sorts of creatures and things and processes" (1954, 93-94). So he concluded that "[t]he program of historical knowing is a case of what we call 'familiarization', the removal of strangeness, where we go (as Collingwood somewhere puts it) from the known to the unknown." $(1954,97)$ In this still rather vague human-interest way Danto here touched on the one point on which $A P H$ agreed with the Historical Idealists, namely that it is the specificity of historical events which interests historians and that this aspect is not covered by nomological explanations. Even so, but for one critical remark in a review of 1955, Danto's published output on philosophy of history by the middle of the 1950s does not show narration to play the central role that his retrospective remark about his first paper would lead one to expect. ${ }^{15}$

Matters change quite radically with what, on account of its substantial nature, appears to be the first published output of the "earlier studies ... abetted

13 See also $(1956,26)$ - quoted in Fn. 16 below - and (1958a, 175). In later installments of his critique the methodology of empathetic Verstehen Danto pointed out its incompatibility with the narrative nature of historical explanations which, as his narrative sentences show, often go beyond the resources available to the historical actors empathized with (1965a, 232; cf. 1966, 573-574).

14 In this respect Danto's paper agreed with Hempel who also neglected to name the "Teutonic" opposition. As in (1953), by the way, Hempel's 1942 paper, was not mentioned: Danto's reference to his (1954) in his later $(1956,21$ Fn. 9) would be misleading if it were read to suggest that the argument there was provided to counter Hempel's claims.

15 Danto's review of Bulletin 64 of the Social Sciences Research Council takes a dim view of its authors' depreciation of "storytelling" in history $(1955,5$ o1). 
by summer grants" prior to his sabbatical in 1961-62 which he noted but did not identify in the Preface to $A P H$ (1965a, viii): "On Explanations in History", published in Philosophy of Science in 1956. There Danto continued his campaign against empathetic Verstehen, ${ }^{16}$ but most importantly placed the notion of stories at center-stage. In a footnote, he admitted to "many very large problems" and referred to "a forthcoming article "Narrative Structures and True Stories"' which would further deal with them (1956, 23 Fn. 13). No paper of this title was ever published, but it is clear that narration in history had begun to form the topic of a project which Danto was pursuing.

"On Explanations in History" represents Danto's first engagement with Hempel's 1942 paper. It also offers the first clear expression of the view that "there is no reason why historical events must remain obdurate to scientific explanation" but that their "explanation in terms of invariant principles misses the point" of history $(1956,19)$. In other words, nomological explanations of historical events were possible yet it was not necessary for history to pursue them. To be sure, history makes use of certain laws "instrumentally", namely it relies on known laws and generalizations (from other sciences) in establishing aspects of what happened, but it does not seek new "explanatory" laws by which to explain what happened $(1956,21)$. Thus Danto judged that "Hempel's thesis is persuasive, especially since he is really only arguing that it is 'in principle' possible to make such [nomological] explanations in history" - to which he added: "but I cannot fully accept the remainder of his thesis" (1956, 22, orig. emphasis). First, Danto noted that already so-called explanation sketches are capable of empirical test, due to their reliance on instrumental laws, and so do not require explanatory laws for that. Second, he noted that the filling out of the explanation sketch is not done by supplying explanatory laws but by filling out the "story" or the "narrative models" that the historian provides. It was "Hempel's mistake", he claimed, "to consider history a pre-science, attending the moment when it too can dazzle us with its proper set of laws" $(1956,25)$. Here Danto announced his break with the logical empiricist orthodoxy he saw represented by Hempel. Narrative methods are not "faute de mieux substitutes for law-like explanations" (1956, 19): the "'filling-in"' of a narrative model does not "yield any law at all, but only more information of a factual sort" $(1956,24)$.

It is notable that already Danto's early narrativism envisaged in very broad terms something like his later compatibilism:

\footnotetext{
16 Danto stressed that "we are able to understand in a much less dramatic fashion than Verstehen recognizes.... Verstehen confuses meaning with acquaintance.... if my language went only as far as my acquaintance, a great deal of discourse would be opaque to me, which it is not" $(1956,26)$.
} 
We must recognize that an identical event may be at once systematically relative (by satisfying some predicate of a scientific language) and $d r a-$ matically relative in the sense I have indicated - but one relation cannot claim any priority over the other, for they belong to different orders of experience. It is the orders of experience which are likely to remain irreducible, not the phenomena themselves which may enter experience on either level. To do a job of history is to carry on with one order of experience, to do a job of science is to carry on with another.

1956,3 O

What Danto here characterized in experiential terms he was to cast in later years into Anscombian linguistic terms: rather than an event being related differently to different "orders of experience", different things were then predicable of an event depending under which description it is dealt with. Still earlier, when disposing of the Teutonic argument, he had already disposed of the idea that history dealt with a different "order of facts" from the sciences $(1954,91)$. Here in 1956, then, we see Danto halfway through his linguistic turn the completion of which is represented by "Narrative Sentences" and $A P H$.

Before we investigate this not insignificant change in the terms of his reasoning about how to conceive of the compatibility of different types of explanation of historical events - note that Danto appears never seriously to have entertained the idea that history does not deal in explanations - consider also how he introduced the idea of stories as what does the filling out of a historian's explanation sketch:

I have elsewhere contended that stories play an important cognitive role in historical inquiry, that a story is an hypothetical recounting of what happened in a more or less determinate stretch of the past, that a story seeks to describe which events 'led to' which other events, and finally, that whatever story we may construct over a stretch of the past, the story must be supported, at critical points, by factual traces. In a sense, such a story is a loosely articulated 'model' of what happened, designating a deployment of events; and insofar as the historian's commitment is to truth, his aim is to draw the model to scale, as it were, so that it reproduces, by some criterion of resemblance, the structure it purports to designate.

1956,23 , orig. emphasis ${ }^{17}$

17 The "elsewhere" appears to be the unpublished paper Danto referred to previously. 
Clearly Danto took his own term "narrative model" quite seriously. What is striking too is that Danto then addressed what criteria of adequacy such a narrative explanation must exhibit: he was clearly aware that it cannot be those of DN-explanations.

Such a story must satisfy at least two conditions: (1) it must account for all the known relevant traces, or at least be consistent with them. But since an indefinite number of stories may be consistent with the same set of traces but at the same time be inconsistent with one another, there is the further condition (2) that the model must suggest further research, so that the positive or negative outcome of such research will tend either to confirm or disconfirm the model. Should such further research unearth a contravening trace, then condition (1) is no longer satisfied ... Should there be two competing models, and the lines of query suggested by each fail to reveal any contravening trace, however indefinitely they may be prolonged, the it is impossible to reject one or embrace the other by any appeal to the evidence.

$1956,23-4$

Danto happily admitted that any story will be incomplete and hypothetical, and that we may remain unable to decide between two of then, but he was adamant that no further provision of laws was needed to improve the explanatory adequacy of the stories provided.

Passages like these may make it seem as if Danto already was more or less in possession of the conception he laid out in $A P H$. (In fact, he may even seem to have gone further for in later years he never returned to consider the conditions of adequacy that narrative explanations should face though he continued to hold them truth-valuable.) Yet Danto was still worried about the robustness of his leading idea and from this it becomes clear that a considerable distance remained to be covered.

I think there are many very large problems raised by the notion of stories, and I am not completely satisfied with the characterization I have given of them either here or elsewhere. For one thing, the earlier statements of a story prepare us for the later ones, and in a sense generate the 'laws' by virtue of which we come to accept the later statements as having been explained. I am willing to consider a story (which purports to be true) as a rather large and complex proposition to be tested in toto. Goodman has recently suggested that 'to seek truth is to seek a true system'... I am not sure whether a story can be constructed as a system of any sort, but 
I think I would vary this utterance by saying that, in history, to seek truth is to seek a true story.

1956, 23, Fn. 13

Unfortunately, Danto did not specify what he thought the "many very large problems raised by the notion of stories" were. Yet note his musings in the second sentence quoted. The idea seems to have been that what connects the statements with which a story begins and ends is a narrative equivalent, "in a sense generated" by the earlier statement, of the general laws that connect initial conditions and terminal state in nomological explanations. What this equivalent might be remained wholly mysterious, however, as did the process of generation invoked. (There are no grounds for regarding this as an anticipation of the later conception of narrative sentences.) But we may take this suggestion to express the problem that Danto struggled with: how stories could replicate the explanatory force that laws possessed in a deductive-nomological argument. Hempel's challenge now squarely had become part of the problem about historical explanation that Danto confronted.

IV

Danto's Lost Paper of $195^{8}$

"On Explanations in History" was not the only publication derived from the studies prior to his sabbatical in 1961-62 that were "abetted by summer grants" (1965a, viii). There also was a second one.18 "On History and Theoretical Science" was published in English in the German journal Studium Generale in $1958 . .^{19}$ What is notable, to begin with, is that this paper does not seem to be mentioned in any other of Danto's writings - it certainly is not listed in the apparently comprehensive bibliography appended to The Philosophy of Arthur C. Danto - or in what scholarship there is about Danto's philosophy of history. If this paper were just a rehash of what Danto had written to date elsewhere, its disappearance from view would be insignificant - but it is not. What is notable, second, is that the paper is declared to be "part of a larger work, now in preparation, which is to be a study of historical inquiry, of familiarization, and of explanation" (1958a, 168 n.). In other words, the footnoted remarks of

18 The paper in question expresses thanks for a summer grant for 1956 in its first footnote.

19 This journal, published by Springer, Berlin, from 1947 to 1971, carried the subtitle Zeitschrift für die Einheit der Wissenschaften im Zusammenhang ihrer Begriffsbildungen und Forschungmethoden (Journal for the Unity of the Sciences in the Context of their Concept Formation and Research Methods) for its first twenty volumes and featured themed issues, with vol. 11 no. 3 (which featured Danto's paper) concerning Geisteswissenschaft. 
his $195^{6}$ paper are here confirmed explicitly (and implicitly related to the presabbatical summer grants): a large-scale inquiry by Danto on explanation in history was now in full swing. ${ }^{20}$

In "On History and Theoretical Science" Danto set out to further explore ideas mooted in his 1956 paper. Here he sought to argue that "the boundaryline separating history from the theoretical sciences ... is real" because "each asks different sorts of questions and requires different kinds of answers" (1958a, 168). Danto may even appear to wish to align himself, as he did not previously, in an old dispute but he immediately added the deflationary comment: "If there is more to be said for the distinction between the Geistes- and Naturwissenschaften, I fail to see what it could be." (1958a, 168-169) The position he argued for wished to be equidistant from Hempel and Dilthey: "Hempel's position is correct but irrelevant.... Dilthey's ... right, but for the wrong reasons." (1958a, 173) $)^{21}$

Third and most importantly, what is notable in this $195^{8}$ paper is how the inquiry was driven forward towards the theory of $A P H$ and in what respects it fell still short of it. Perhaps most striking is that this paper employs an argumentative device for the first time that is also prominent in the book, the "inconsistent triad". 22 "1. All explanations require the employment of general laws. 2. Historians sometimes explain some events. 3. Historians do not employ general laws in their explanations." Danto accepted (1) and (2) as relatively uncontroversial and focused on (3) as "the weakest proposition in the triad" (1958a, 176). Under this heading Danto repeated his criticism of Hempel as making a good ontological but a "misleading" methodological point. This is followed by Danto's longest statement of the narrativist thesis to date, clearly intended to reveal his preferred alternative answer to the problem represented by (3). (No survey of all the positions possible, as in $A P H$, was undertaken.) Having called what historians aim for "specifications" of events - detailed and, importantly,

$20 \quad$ Whether "On History and Theoretical Science" is a retitled version of what Danto had referred to under the title "Narrative Structures and True Stories" as forthcoming in his (1956) or another offshoot of the larger project in progress already then is impossible to tell at this stage.

21 Apart from Dilthey (1894) - notably not (1883)! - Danto referred to Rickert (1902).

22 The recitation of the same three propositions and the problem of making them compatible was also introduced as generating the problem of historical explanation for expository purposes in Danto's review of Dray (1957), albeit only for expository purposes. There Danto advanced no solution. Instead he applauded Dray for having shown that the DNmodel is uninformative about "the actualities of explanation in history", but criticized Dray's view that "rational reconstruction is a wrong, rather than a different way of doing philosophy": the DN-model was "intended to explicate, not duplicate the practice of empirical scientists" (1958b, 299). 
authenticated descriptions - he noted that "the way in which the historian's specifications are presented is in narrative form". Still more importantly, Danto now claimed that "a story is an explanation" (1958a, 177, orig. emphases). The filling-in that the historian's explanation sketches require is not the provision of laws but of narrative detail, moreover, as he now put it: "Historians confirm no laws but they do confirm narratives." (1958a, 178)

Wherein then lies Danto's advance on his $195^{6}$ paper? A comment that he "regret[ted] not having been able to analyze further the logic of narrative structures, and subsidiary matters of confirming, disconfirming and modifying such structures" - what he regarded as "the central problems for any philosophical analysis of historical inquiry" - may suggest that all he did was look at the issue from the perspective of the "puzzling boundary" between Naturand Geisteswissenschaften (1958a, 179), albeit with a new argumentative slant. But this would be wrong. While acknowledging still important outstanding problems, Danto now was much more affirmative in holding historical explanations to be essentially narrative in character (vide his formulations in the indicate mode: "a story is an explanation"). Previously Danto still conceded that a nomological explanation based on social science "might eliminate the need for narrative models or 'true stories", albeit only "if our concrete interests in history were to be extinguished", and so was left with the rhetorical protest: "But what if history were not, after all, an incomplete science, but a consummatory enterprise, satisfying a special requirement of the human spirit?" $(1956,25)$ By contrast, now he asserted firmly:

Even if science were to advance to a point where every single utterance in a narrative could be exhibited as a deductive consequence of some set of laws and initial conditions, still, the sum of all these 'rightangle' explanations would not be an explanation of the event in the same sense in which the narrative they justify is an explanation of it.

$1958 \mathrm{a}, 178$

Historical narratives are not only legitimate in their own "dramatic" sphere, but now they are legitimate also in providing explanations themselves. Thus he concluded:

By recognizing that one sense of the word 'explain' is 'to make clear what happened', and that one way of making clear what happened is to tell a true story, I think there is a way out of the 'inconsistent triad' I proposed above. And particularly one may, if I have been correct, see what role general laws play in history.

$1958 \mathrm{a}, 179$ 
Note also that Danto now had silently dropped as wholly inappropriate any suggestions along the lines that the earlier parts of a story "generate 'the laws' by virtue of which we accept the later statements as being explained" (1956, $23 n)$. Yet he still clearly anticipated a distinct "logic of narrative structures" to be developed. Indeed, the need for such a logic became evident as he continued to explore the compatibilism he envisaged. Thus he indicated his suspicion about the shortcomings of nomological explanations that may justify narratives: "What would always be lacking would be a general temporal law accounting for the sequence of the total event", i.e. a law not at "rightangle" to the narrative at issue (1958a, 178 , orig. emphasis). ${ }^{23}$ So there was between the 1956 and $195^{8}$ papers a very significant development. Somehow or other, stories were now regarded as capable of doing the job of historical explanation more or less all by themselves.

But wherein did Danto's 1958 position still fall short of his in $A P H$ ? The most obvious answer is that as yet Danto was unable to tell just how stories could do the job more or less by themselves. The second obvious shortfall is that he hadn't yet hit upon the phenomenon of narrative sentences. (This idea was worked out into a paper only in the summer of 1961.) Thus we may also note that perhaps the most important ingredient necessary to comprehend that phenomenon was also still absent. In concluding the paper he noted that "[h]istory is unique amongst the sciences in possessing no technical vocabulary" and that because of it "history discharges a function which no other discipline, and certainly no other theoretical science, could discharge as effectively". It is that "in making other worlds familiar, the historian makes this world less so" (1958a, 179). Great importance was thus granted to the descriptions which historians furnish to give us access to these unfamiliar worlds. Much then was already in place for the imminent discovery of narrative sentences, but what was strikingly missing as yet was the notion of the same events being related under different descriptions. What was needed still was the recognition that "there is a class of descriptions of any event under which the event cannot

23 Danto suspected the reason to lie in the fact that history's explananda are unexpected or unusual events: "Can there in principle be such a temporal law? I cannot say, of course, but I suspect not. One reason why I am dubious is that it is always possible to find counter-instances to every part of that law. And the reason for this is that the event itself must already be a counter-instance to that class of events which happen 'always or usually'." (1958a, 178) Note that $A P H$ explored different reasoning to conclude that "no general law need be found to cover the entire change covered and explained by the narrative" (1965a, 255). 
even be witnessed, and these descriptions are necessarily and systematically excluded from the I[deal] C[hronicle]" (1962, 154/1965a, 151, emphasis added). ${ }^{24}$

That Elizabeth Anscombe's locution "under a description" and her observation that what is true of an event under one description may not be true of it under another played an important role in the history of post-World War II philosophy is well known. Both Danto and Donald Davidson made excellent use of this insight in clarifying how on Hume's theory causal laws apply to their instances. ${ }^{25}$ Both also incorporated the resultant difference between the descriptions given of types of events in the formulation of laws and the descriptions given of their instances into their solutions of inconsistent triads of propositions concerning the role of general laws in historical and psychological explanations, respectively. ${ }^{26}$ For Danto, Anscombe's locution and the distinction it allowed was one of the two prerequisites for the discovery of narrative sentences, the other being Russell Norwood Hanson's reflections about "the role that theory plays in scientific observation" (2013a, 29). But while Danto briefly wondered whether "a story can be regarded as a theory" he dismissed the suggestion on account of a story being "about one and only one event" and

24 This is the sentence which had attached the footnote: "In her book, Intention, G.E.M. Anscombe points out that there are many descriptions of an action, only under some of which it is intentional. I think this is a considerable insight, and I want to acknowledge that my own thoughts here were directly stimulated by Miss Anscombe's book." (1962, 154n/1965a, 393)

25 Davidson wrote: “It may mean that 'A caused B' entails some particular law involving the predicates used in the descriptions ' $\mathrm{A}$ ' and ' $\mathrm{B}$ ', or it may mean that 'A caused B' entails that there exists a causal law instantiated by some true descriptions of A and B." The descriptions "under which" events are described thus play a crucial role for the argument that "ignorance of competent predictive laws does not inhibit valid causal explanation" $(1963 / 1980,16)$. Danto $(1973,97-98)$ agreed with this way of accomodating the fact that "singular causal ascriptions entail laws ... even if we do not know which law in fact is entailed by such ascriptions.* But this may be explained through the fact that we may not know under what description of $a$ and $b$ the latter is causally dependent upon the former." Fn." refers approvingly to Davidson $(1967,701 / 1980,160)$ which reiterates the 1963 point. With an eye to a future critical examination of Danto's compatibilism it may be noted that while it comes easy nowadays to understand its relation between nomological and narrative explanations on the model of Davidson's reading of Hume, it is not clear whether that was his intention at the point of its inception. And it must be added that the anomalous monist solution is not universally held to be unproblematical.

26 Davidson's triad was: (i) At least some mental acts interact causally with physical events; (ii) where there is causality, there must be a law; (iii) there are no strict laws on the basis of which mental events can be predicted and explained. See Davidson (1970/198o, 208; cf. 1973/1980, 250-1 and 1974/1980, 230). 
neither being "itself a law" or "contain[ing] laws as parts of itself" (1958a, 177). So Danto did not yet bring to bear, it seems, Hanson's insights either. ${ }^{27}$

Another absence in the $195^{8}$ paper concerns not a presupposition of the possibility of narrative sentences but a consequence of it. This is obvious but significant nevertheless. It is that history is open as long as the future is open. This is significant not because Danto's papers on history in the 195os argue that history was closed - they simply assume it without discussion - but because of the logical space that opens up with the recognition of narrative sentences: history is inexhaustible and far exceeds what even contemporaries could have witnessed in as much as indefinitely many true descriptions of any event become available with the happening of later events and new ways of conceptualizing earlier ones. The opening of history effected first by "Narrative Sentences" and elaborated in $A P H$ altered the very concept of history current up to then. The $195^{8}$ paper still belonged to a world in which history did not change.

In sum then, Danto's publications on history in the 1950s show a distinctive development towards his later view as elaborated in $A P H$ - with the crucial difference that the "under a description" locution and recognition of the theoreticity of observation and its relevance for historical description, and with it all that they facilitated, were still missing.

\section{Danto's Dissertation}

To get as full a sense of Danto's philosophical development as possible, not only must his pre- $A P H$ publications be considered, but also his unpublished $\mathrm{PhD}$ dissertation. Then it can be seen even better that while Danto became a philosopher of science at Columbia while on a tenure-track position, his primary engagement was with philosophy of history.

The title of Danto's $195^{2}$ dissertation, also at Columbia, is "Acts and Histories". ${ }^{28}$ About it he only made the following puzzling remark:

27 I return to the question of when Danto incorporated the Anscombian and Hansonian insights in sect. 6 below.

28 The dissertation does not indicate the members of his dissertation committee, but I suspect Nagel and Randall were involved. Extant Columbia records also do not list Danto's examiners but they name Randall as his PhD advisor. (I thank Jocelyn Will and Esmeralda McCormick of Columbia University Archives and Dissertation Office for this information.) 
I wrote a dissertation on the philosophy of history. It was certainly original, but I knew immediately after I defended it that I had a long way to go before I was able to write significant philosophy. In subsequent discussions I would sometimes lay out a position which others would insist no one in their right mind would hold. Well, I said, $I$ had held it. The value of having written it, apart from the practical advantages of being a $\mathrm{PhD}$, was that I was the one everyone else would have thought a straw man.

2013a, 12, orig. emphasis

Danto did not tell what the "straw man" position was and it is not immediately obvious from the dissertation either. It is unlikely to be the overall thesis defended for that is a version of the well-worn position of historical idealism even though it is one Danto sought to specify and defend on his own conceptual terms and independently of any incarnation in Croce, Collingwood or, indeed, the purveyors of the Teutonic argument. ${ }^{29}$ To interpret Danto's retrospective comment we must consider the dissertation in somewhat greater detail.

The overall thesis is that history is the history of acts. "When a star falls, or a tree grows, these are happenings, but they are not the sort of happenings which are to be of immediate interest to us. We are not interested in everything that happens ..." (1952, 13, orig. emphasis) The striking act-centricity of history is proclaimed on its opening page.

History is the inseparable accompaniment of actions, or, as we shall prefer to say, history is the automatic precipitate of an act: it is impossible to speak of an act which has no history, and it is awkward to try to conceive of a history which is not the precipitate of some act, or some continuity of acts, or of some complex of acts.

$195^{2}, \mathrm{i}$

Each act which actors perform

increments the history which has already been precipitated and the history which has already been precipitated is reflective of acts which are now influencing, or conditioning, the new acts which are being or will be performed. The accumulated historical perspective of past actions is with us whenever we launch some new integration and actors must

29 The number of references in the dissertation is relatively moderate, but the number of those to Croce (1952, 15n, 23n, 27n, 33n, 75n) and Collingwood (1952, 8on, 94n, 359n) lead those to philosophers of history. 
carry with them their histories as surely as Marley's Ghost drags behind him the accumulation of cash boxes to which an existence of penury has chained him.

$1952, \mathrm{i}$

Danto distinguished between (i) history, (ii) 'history', and (iii) *history*.30 These terms distinguished (i) what happened from (ii) inquiry into what happened and (iii) narratives which set down what happened. ${ }^{31}$ Accordingly,

history shall designate the totality of histories, precipitated by all the acts which have been performed in the continuance of existence up to the present moment. Some of these histories, 'history' maybe aware of, and some of them not, and some of them may be of no immediate interest to the historian at all, and hence may be written of in no *history* whatsoever.

1952, 20, orig. emphases

History no longer was the domain of "great men" - what had been a not untypical assumption of the historical idealists - but it had become everybody's fate. Yet other traditional assumptions - like its "eternal immutability" - and organizing principles - like "action" and "purpose" - remained "indispensible" to history. ${ }^{32}$ Danto also held that while "the act itself is never recapturable in the immediacy which the actor felt", it remains the case that for the historian "what happens in the act is always the ultimate subject of his inquiries.... He

30 I use asterisks in place of double quotation marks for (iii) to facilitate my quotations. This notation was not used by Danto.

31 Each of them has a distinct set of problems assigned to them: those of (i) are ontological, those of (ii) epistemological, and those of (iii) aesthetic. Thus (i) asks: "what is the nature and structure of that mode of existence which we term historical?", (ii) asks "how do we know about history?", and (iii) asks "how can we best narrate the information we have about some moment or other of historical existence?" (1952,13-14). "Section 1" of the dissertation deals in four chapters with aspects of issue (i), "Section 2" in three chapters with aspects of issue (iii), and "Section 3 " in two chapters with aspects of chapter (ii). Over the course of 360 double-spaced pages (footnotes single-spaced) the main thesis is repeatedly laid out and various of its implications are drawn out under these headings. Danto's dissertation is perhaps best seen as laying down conceptual groundwork for later, more penetrating inquiries. But my aim here is not its evaluation but to detect starting positions for his career as a philosopher of history.

32 That "history remains eternally immutable" is held to be an "indispensible" assumption (1952, ii; cf. 276-279). Likewise "the concept of action is indispensible to historical inquiry" as "an organizing concept" (1952, v), as is "the concept of purpose" that is correlated with it $(1952,346)$, for "it is about acts that anyone who asks an historical question is really asking” (1952, viii). 
only asks questions about what happens outside of acts when the answers to these questions will help him understand what happens inside acts" (1952, 38 and 143, first emphasis added). Echoes of Collingwood are unmistakable. ${ }^{33}$

Needless to say, this conception is not above criticism. To claim that "institutions, economic cycles, art movements and the like" are not excluded from history because "we can describe and analyze an institution in terms of acts" (1952, 138, orig. emphasis) does not solve the problem. This defense either depends on a straightforward reductionist claim - talk of institutions is a "convenient short-hand" $\left(195^{2}, 139\right)$ - or on an understanding of action that exceeds the purely intentional phenomenology it confesses to and incorporates its entire causal history. Both lines of defense are very controversial.

That said, Danto also noted as "one main consequence of distinguishing in this way between action and history" the fact that

there is no special sense in looking for unique historical laws of any sort. So far as we are to be concerned, there may be, and there no doubt are, laws of action; but there are no laws of history which would be different from laws of action.... Each act, which is an instance of the descriptive law, has a history; but there are no special laws describing the histories of the acts which are different from the laws describing the acts themselves.

1952, 39-40, orig. emphasis

Danto also briefly turned to the applicability of nomological reasoning to history in general and concluded that "the historian, using principles and techniques and modes of inference derived from the sciences, is not interested in these generalities as such, but with [sic!] the particular acts, whose histories their application illumines" $\left(1952,59\right.$; cf. 110, 145, 148). ${ }^{34}$ Note that this

33 Elsewhere Danto talked of "problems ... 'internal' to ... acts" $\left(195^{2}, 232\right)$ and stated: "It is the task of 'history', then, to find out what happened in and what happened to acts. What happened in the act is the history of the act. What happened to the act is the relationship which the act has with other acts (or the histories has with other histories)." (1952, 239, orig. emphases) Ankersmit's comment that he does not know of "any influential AngloSaxon philosopher of history who is less interested and inspired by Collingwood than Danto" (2007b, 370/ 2009, 145) evidently fails to take account of Danto's philosophical beginnings.

34 It is in the related context of noting that arguments have been put against the view that history is entirely concerned with unique and unrepeatable events that one brief but wholly unelaborated reference to Hempel (1942/1949) is made at (1952, 57 Fn. 2). 
conclusion can be read as broadly anticipating his later distinction between historians borrowing but not seeking to discover laws. ${ }^{35}$

With history defined in his fashion Danto owed a definition of what acts are, of course. He rejected Maurice Mandelbaum's determination $(1938,222)$ of "the proto-physical event as the ultimate reference for 'historical' inquiry" for the reason that "the fact of [this] identity provides no criterion for determining which events are historical and which non-historical" $\left(195^{2}, 44\right)$. Yet beyond the bland assertion that "all phenomena which occur in nature are by definition natural, but this does not mean that all phenomena are the same, or 'in the same sense' the same" $(1952,46)$ Danto offered no ontological characterization of acts differentiating them from other kinds of happenings. Instead he rested with the observation that "the language we use when we speak of historical phenomena is not the language we use when we speak of physical phenomena" (1952, 45, orig. emphasis). (Again we may detect a broad anticipation of a theme much to be elaborated in later years.) For the purpose of defining "acts" Danto adopted the "action frame of reference" from Talcott Parsons (1949), an "irreducible framework of relations between ... elements ... without which talk about action fails to make sense", these elements being the ends, means, conditions and norms of actions as well as temporal references $(1952,65)$.

Danto adapted Parson's synchronic frame of reference for use in history by extending it to action sequences, making explicit the future-orientation of acts and introducing, from Dewey's Logic (1938), the concept of a problem situation which requires a decision on the part of the actor and to which actions must be regarded as responding for a reason. Action is "behavior characterized by the making and carrying out of decisions when these decisions are solicited by a conditional problem, and colored by certain anticipated and valued ends" $(1952,102)$. Building on this, Danto offered observations on the structure of narration, especially on how different acts must be related to each other in order to figure in one narrative. He concluded that "acts may be related irrespective of how they are related temporally, spatially or personally" $(1952,193)$. Focussing on the fact that "at the heart of every act lies a problem" $(1952,196)$ he arrived at the thesis "that it is the persistence of some problem which relates acts to one another in some sort of rough continuity" $(1952,198)$. It was just the lack of such continuity that distinguished a chronicle from a "*history" $(1952,162)$. The acts of one individual are all related in the most minimal way by the problem of survival, while other acts of an individual are related more closely by a

35 Note also that the example used $\left(195^{2}, 60\right)$ - an astrophysicist making use of ancient Chinese records to confirm an astronomical hypothesis - was employed again to make the same point in $(1954,93)$. 
particular purpose. Acts which are related in a series "need not be performed in any immediate succession": time gaps between members of a series are allowed, as when we "lay a problem aside" $(1952,201)$. Different actors may also be interested in the same problem, so the persistence of an identical problem throughout a series of acts by different actors constitutes another continuity investigated by historians. ${ }^{36}$ Besides these continuities of act-series, another type of conglomerations of acts that interests historians are act-clusters: these are complexes constituted by the intersection of different act-series. "When two acts meet in a cluster, it is because their respective decisions have brought them there, although the decision to move in a direction on the part of act $\mathrm{A}$ need have nothing to do with the decision to move in another direction on the part of act B." $(1952,222)$ In sum:

Acts are related internally into series and externally into clusters.... It is the clusters encountered in the course of acting that make series the erratic affairs that they are, rather than equably progressing streams, moving toward some goal of their choosing.... Series and clusters will, if the metaphor be permitted, constitute the strands (the series) and the knots (the clusters) which together constitute the irregular fabric of the historical past.... Thus the topography of that domain of experience, the understanding and the narration of which is the task of historians, consist of a network of such strands and knots - a tangled skein of purposes and cross-purposes, where the continuance of the former and their intersections articulate the historical past.

1952, 228-230, orig. emphases

His scheme, Danto concluded, allowed historians "at one end of specialization" to focus on "a single event" and those "at the other end" to investigate "an indefinitely large collection of events" $\left(195^{2}, 244\right)$. And it showed the concept of action to be "at once regulative and constitutive, and as a necessary condition for the possibility of 'historical' questioning and answering": it was the historian's focus on action that ensured the disciplinary autonomy of history $(1952,245)$.

Notably Danto's account left out of consideration, perhaps did not yet notice, features of narratives that do not map onto acts and their concatenations. (As in his early published papers, that history represents the past by narratives

36 Needless to say, Danto's example here, the *history* of philosophy, is bound to raise the issue of anachronism, even if allowance is made for the conviction that "we feel, as a matter of fact, that any act which could be called a philosophical act, is somehow significantly related to other so-called philosophical acts." $(1952,207)$ 
was simply taken for granted.) In consequence his epistemological inquiry was limited to combatting standard forms of skepticism about historical knowledge and did not extend to the peculiarities of narration. The skepticism Danto dealt with fed off a variety of unobservabilities (past events, other people's actions) and ultimately turned radical - at which point it was faced down with the help of Norman Malcolm. ${ }^{37}$ When all criteria for thinking a historical statement true have been met, it simply makes no sense to press doubt any further: "If someone wants to prove us wrong, let him do so in the proper way. The appeal to philosophical principle is not the proper way." $(1952,340)$ Moreover, the same holds for "arriving at true statements regarding purposes" as for "arriving at true statements about any piece of history": "We use the device of consistency, cumulations of c-statements, and we refer, whenever possible to the facts." (1952, 36o; c-statements are "about particular aspects or moments of histories".) While historical truth seems defended here in a common sense way, we must note that it depends on an extremely strong form of realism. It depends on taking historical accounts to consist in all relevant aspects of factual statements and to regard true historical accounts as pictures true to the facts.

For purposes of validation of historical accounts, Danto distinguished between "c-statements" and "C-statements", that is, between "contributory statements ... made about particular aspects or moments of histories" and "complete 'historical' statements consist[ing] of a total conjunction of all possible contributory statements about a history" $\left(195^{2}, 282\right)$. When he went on to declare that " $\mathrm{a}$ "history" proposes, as far as possible, to be just such a complete statement" Danto was fully aware of the idealization he was engaging in, for he also stated that "the concept of C-statements ... serves a regulative function and lends direction" (1952, 288). Accordingly, with the further proviso that "all the c-statements must be true", the epistemological problems posed by history reduce to two: "(1) Are all the c-statements made and (2) are all the c-statements true?” (1952, 288, orig. emphasis). Concentrating on question (2), Danto noted, to start with, that "the key c-statements in any conjunction of c-statements are fact-anchored."

By facts, in respect to 'historical' inquiry, we mean (roughly) material evidence. We mean such things as monuments, coins, kitchen middens, weapons, ruins, manuscripts, letters, inscriptions, costumes, records of vital (and other) statistics, photographs, fingerprints, recordings made 
of speeches, jewels, vehicles, engravings, transcribed testimony, and any number of other things

1952, 297, orig. emphasis

So facts, for Danto, are the traces of human activity that key parts of historical accounts are based on. Distinguishing further these fact-anchored c-statements as " $\mathrm{c}_{\mathrm{f}}$-statements" from merely inferred c-statements as " $\mathrm{c}_{\mathrm{i}}$-statements", this means, given the proviso stated, that "for every $\mathrm{c}_{\mathrm{i}}$-statement there must be a $\mathrm{c}_{\mathrm{f}}$-statement to make it true" $\left(195^{2}, 302\right)$. (Clearly, in light of well-known underdetermination considerations, Danto's talk of "validation" must be read as mere confirmation or disconfirmation.) This leaves, of course, the question of how to "authenticate a $\mathrm{c}_{\mathrm{f}}$-statement". And the answer to this, given the vacuity of philosophical skepticism, is simply whether it is verified by one of the facts listed above in ways that comport with accepted scientific standards.

Danto was aware that his analysis so far led to an "almost granulated conception of 'historical' knowledge" and he admitted that "it is interesting but insignificant to disinter information unless the information is amenable to some form of organization." (1952, 341-342). "*Histories*”, by contrast, "as the narratives of what happened in at least a single act, strive to reproduce, or reconstruct the order of moments which finally become stabilized with the completion of the acts in question." $\left(195^{2}, 343\right)$ Yet if his readers were to expert now a disquisition on narrative principles they'd be disappointed; instead, Danto fell back on the "organizing principles" previously identified.

If we exchange the term *history* for the term $C$-statement, then an *history* is a sort of picture of a history: if our knowledge is perfect, then the *history* is a perfect portrait. If our knowledge is fairly complete, then the *history* is perhaps a 'good likeness'. And if our knowledge is inadequate, our picture is to that degree distorted, vague, ill-defined, or features are missing. The concept of the act, as a prior organizing form of inquiry, however, serves as a reference in terms of which we can sometimes know which features are missing, which forms are vague, and so forth. The picture as a whole is a C-statement, and the elements of the picture are the c-statements, which are asserted of the manifold moments and aspects of the history of an act. So, as a principle of organization, the concept of an act is crucial to the understanding of a history, as well as to the forming of a 'picture' (a *history*) of the history in question. For the concept guarantees that the order of true 'historical' c-statements shall reproduce, and be in accordance with, the order of the happening itself. 
Danto's conception of historical truth here is that of correspondence, of delineating a given temporal and causal order organized by the concepts of act and problem (or action and purpose). It is this unabashed and unmitigated historical correspondence realism that, I hypothesize, Danto was thinking of when he recalled some sixty years afterwards that he himself once had been the very straw man that many philosophical discussions of history dismiss. According to it, historical accounts consist in all relevant aspects of fact-stating statements and true historical accounts are pictures true to the facts.

\section{Danto's Philosophical Development}

Before drawing a preliminary conclusion, we may note a couple of passages in his dissertation that will help us see still better what it took to discover the phenomenon of narrative sentences and to reach his distinctive position visà-vis Hempel.

Act-series and act-clusters were distinguished in the dissertation in that in the former case but in not the latter the individual events had an internal relationship with each other: "here we often could not conceive of the latter act happening without the former act having happened." But this does not mean that in act-series "we could always predict, from a given act, what future act would be seriated with it. Only ex post-facto-wise are we able to see how some act is seriated with the former act." (1952, 228-229) Just such ex post-facto-wise seriations are, of course, what narrative sentences wear on their sleeve (but not only concerning acts). Yet Danto paid no further attention to them as he did not consider statements asserting such ex post-facto-wise seriations to be statements about "the history of an act" in his specific sense. With histories being what an act has precipitated by the time of its completion, the relevance of narrative sentences was in effect ruled out. ${ }^{38}$ In $A P H$, of course, Danto was no longer restricted by the ontology of acts as individuated by their purpose; instead he referred to the objects of historical inquiry as events that could described in the most manifold of ways. This points to a precondition of his later

38 In a footnote to his discussion of temporal statements - "'historical statements', if once true, are always thereafter true" $\left(195^{2}, 269\right)$ - Danto quoted as a possible exception to this principle from Anscombe $\left(195^{\circ}, 5^{\circ}\right)$ the observation that "Aristotle described the use of the Greek word which we translate 'involuntary' in such a way that an action can become involuntary if it produces consequences which the agent regrets". Yet Danto evidently resisted the suggestion to "include as part of our statement of the history of an act, things which happened after the act" (1952, 269n). 
view not noted so far, namely that it demands an historical ontology that allows such unlimited redescriptions.

One of the presuppositions of Danto's early account was that of the immutability of history. As just noted, this did not only encompass what happened (which cannot be made not to have happened) but also extended to what can be said truly of the objects of historical inquiry. "With histories (as opposed to acts) all the results are in, and await tabulation." (1952, 270). Danto employed this notable illustration of his view:

Suppose, from some repository, that objects are placed upon an endless one-directional conveyor belt. Let us imagine that these objects, once they have been placed upon the belt, may never be dislodged or removed therefrom.... The belt is a metaphorical way of talking about time. The objects are metaphorical ways of talking about histories. The repository is a metaphorical way of talking about the future.... What follows ... is, of course, that histories, once having come to be part of the inventory of the present, remain immutable: it is absurd to speak of histories as changing or changeable. Our views about them may change, but they themselves are forever stable.

$1952,274-276$

This conception leads quite naturally to the view of history that Danto immortalized in his parable of the Ideal Chronicle (1962; 1965a, Ch. 8). If history is what an act precipitates in being performed, then history is what an ideal observer with access to all regions of space and all other minds can record the moment it is happening. To mix Danto's metaphors, the Ideal Chronicle records what is being placed on the belt while it is being placed on the belt. If moreover history is only what an act precipitates as it is being performed, then there is no more to history than what an Ideal Chronicle can record - contrary to what narrative sentences were to teach.

Crucial for keeping the possibility of narrative sentences invisible is, again, the determination of the objects of historical study as acts and the attendant sharp distinction between history as determined by the completion of an act (and the manifestation of the intention behind it) and whatever happens afterwards. But the other two preconditions for the recognition of narrative sentences are by no means rendered irrelevant. Without awareness of the applicability to history of the Hansonian theoreticity of observation and the Anscombian truth-variability of ascriptions to entities under different descriptions, the change in ontology did not make enough of a difference (as the history of Danto's views shows). Finally, note again that not only was Hempel's 
challenge to history not engaged with in the dissertation to any extent nomological explanations do not respect the intentionalist strictures Danto observed - but also that there was no significant talk of explanation as such. ${ }^{39}$

The question as to when which of these changes needed to recognize narrative sentences and to reach the $A P H$ position (they are not identical) were made is difficult to answer conclusively in all respects. But it can be answered more or less roughly as follows. Since none of his publications, which begin in 1953, give an inkling of the early historical idealism, it is a fair guess that Danto abandoned it very soon after the completion of the dissertation itself. Perhaps he was even disabused of its tenability in the course of its defense. In any case, by 1953 he had switched the ontology to events, but since his dissertation remained unpublished his reasons were not discussed. ${ }^{40}$

Hanson and Danto were fellow graduate students at Columbia prior to both taking up a Fulbright scholarship in 1949, Hanson going to Cambridge (and not returning to the United States until 1957) and Danto going to Paris (returning to teach in Colorado in $195^{\circ}$ and at Columbia from 1951). Hanson's Patterns of Discovery was published in 1958 and the anthology on philosophy of science Danto published with Morgenbesser in 196 o featured Hanson's work. ${ }^{41}$ So

39 For instance, his rare use of the term explanation at $\left(195^{2}, 205\right)$ does not signal engagement with the philosophical problem of explanation; Hempel and Oppenheim (1948) are nowhere mentioned.

40 In (1953) Danto simply spoke of events as the objects of concern to historian. I note that an event took place at the American Philosophical Association's annual meeting at City College in New York on 29-31 December 1952 that would have confirmed any critical reaction to his historical idealism at his $\mathrm{PhD}$ defense and also provided similar worries on its own: a symposium on issues in the philosophy of social science with Nagel and Hempel. (Given the event was local and featured a teacher-turned-colleague it is likely that Danto either attended or read the published version or both.) While Nagel addressed mainly issues of functional explanation (1952), Hempel discussed Max Weber's ideal type methodology and in due course stated about his overall claim about the nature of sociology: "Weber's limitation of the explanatory principles of sociology to 'meaningful' rules of intelligible behavior ... is untenable: many, if not all, occurrences of interest to the social scientist require for their explanation reference to factors which are 'devoid of subjective meaning' and thus 'non-understandable uniformities'" $\left(195^{2} / 1965,163\right)$. Nagel can be assumed to have shared already then this view of what he later called Weber's "restrictive" definition $(1961,473-476)$. The implication of this rejection of Weber's exclusivist interpretivism for Danto's historical idealism is plain: there is no good reason to limit history to intentional action either.

41 While the anthology only features a specially abridged version of Hanson's 1959 paper on quantum theory, the influence of his work on observation can be detected in Danto and Morgenbesser's "Introduction" to "Part One: Science, Language, Experience" (1960, 25), while Hanson (1958) was listed in the bibliography (1960, 472), albeit dated to 1959. 
the theoreticity of observation can be presumed to have been known to Danto from at least 1958 onwards. ${ }^{42}$

This leaves Danto's acquaintance with the locution "under a description" which he first used in "Narrative Sentences", written in 1961. Now the first issue of Journal of Philosophy 56 of January 1959 carried a review of Intention which began: "Miss Anscombe's book is easily one of the best things to come from England in many years" and employed phrase "the description under which an action is intentional" already in the third paragraph. The review was written by Judy Jarvis (Thomson), then a Lecturer at Barnard College and about to receive her PhD from Columbia University. It was of her as "one of my closest chums in those days" that Danto reported: "it was with her that I first discussed narrative sentences. I am not sure that either of us saw them at first as anything more than logical curiosities, but we loved finding funny examples" (2013a, 16). It would seem then that Danto became acquainted with Anscombe's locution when Jarvis was writing the review in 1958 (if not before). Now when precisely the idea of narrative sentences was first hit upon and when they were recognized to reveal the philosophically significant deep structure of historical explanation Danto did not say, but it is clear that by 1961 the idea had gelled sufficiently to prompt his writing "Narrative Sentences" over the summer. Whether at the time of writing it Danto already had an idea of the details of his APH response to Hempel's charge is unclear, but at least the basis on which his compatibilism was to be built was plain: history concerns events of which descriptions in different idioms are true. It is this that distinguishes the 196os version(s) of his compatibilism from that already envisaged in the papers published in 1956 and 1958.

So much for the essential steps on the way to $A P H$. But has light been thrown on Danto's motivation for his compatibilist theory? The realization that Danto was a philosopher of history first and a philosopher of science second allows seeing the dynamics of his development more clearly. The movement was away from the historical idealism that marked his dissertation to reach, within a dozen years, that of $A P H$. Importantly, this new position allowed him to retain a narrativist conception of history under what he had come to regard as conditions of scientific respectability.

42 Danto himself reported: "I felt that with narrative sentences we had a class of exceedingly important descriptions under which the events of which they are true could not have been observed. I tend to think this concept came from my old classmate, Russ Hanson, whose Patterns of Discovery opened my eyes to the role that theory plays in scientific observation. Hanson wrote of observation being 'theory-laden'." (2013a, 29) 
This trajectory runs counter at least in spirit to Ankersmit's assertion that Danto's never having "closely studied Collingwood ... may explain why he, unlike most other Anglo-Saxon philosophers of history, did not allow himself to remain enclosed with the narrow limits of intentionalism" (2007b, 393/2009, 144). As we saw, Danto had read his Collingwood and even held an idealist position in his dissertation: he once was so enclosed but did not remain so. In fact, giving up this intentionalism by giving up the act-centrism of his earliest philosophy of history was part of Danto's becoming a philosopher of science. The next step was to begin his critical engagement with Hempel over the nature of historical explanation in his (1956) and (1958). The trajectory here outlined thus also suggests that Ankersmit's claim (2007b, 369/2009, 115) that Danto only "hesitantly embraced" Hempel's model of explanation in $A P H$ is mistaken. Danto not only expressed strong agreement with Hempel's model still afterwards (1968a, 124), but even twenty years later he remarked that it still struck him "as true" and only "stopped being relevant" (1995, 85).43 Early on as a young philosopher of science, moreover, Danto had to find a place for historical explanation among the sciences and this meant that he had to find a way to show it at least compatible with the account of explanation that was accepted - and that he accepted, explicitly and without qualms since the mid1950s - as characteristic of the sciences: Hempel's.

With $A P H$, finally, Danto seemed to be able to stabilize the anti-reductivism that his concern for the autonomy of history required. But then, as Danto also remarked, the world changed with Kuhn's Structure when science itself became historicized and purely logical explications like Hempel's became irrelevant (or at least were regarded as such). His few return engagements with philosophy of history since, as in the last two essays added in Narration and Knowledge, once again neglected the issue of explanation and explored more broadly phenomenological, even existential, aspects of history and historical consciousness. ${ }^{44}$ Needless to say, perhaps, the problem of explanation has not gone away, but that is another story.

43 This last comment is worthy an exegesis in its own right, but not here. Danto also provided several descriptions of $A P H$ 's relation to Hempel that do not, however, speak with one voice; cf. (1985, xii), (1995, 71), (2007a, 226-227), (2013a, 16), (2013b, 112).

44 See Danto (1973b/1985b, 298-341) and (1982/1985b, 342-363) and note his comment that "narration yields certain categories of thought that might be said to compose the metaphysics of everyday life" (1985a, xiv). 


\section{Acknowledgements}

A short version of this paper was presented at a workshop on the philosophy of history at INTH 2018 in Stockholm. I wish to thank Paul Roth for inviting me and him and members of the audience for asking stimulating questions. Thanks are also due to Tom McCutchon at the Columbia Rare Book \& Manuscript Library.

\section{Bibliography}

American Philosophical Association (ed.). 1952. Science, Language and Human Rights. Philadelphia: University of Pennsylvania Press.

Ankersmit, Frank. 2007a. "Danto, History, and the Tragedy of Human Existence." In Herwitz and Kelly 2007, 175-189.

Ankersmit, Frank. 2007b. "Danto's Philosophy of History in Retrospective." In Danto 2007b, 364-393

Ankersmit, Frank. 2009. "Danto's Philosophy of History in Retrospective." Journal of the Philosophy of History 3, 109-145.

Anscombe, G.E.M. 1950. “The Reality of the Past.” In M. Black (ed.), Philosophical Analysis. Ithaca: Cornell University Press, 38-59.

Anscombe, G.E.M. 1957. Intention. Oxford: Blackwells.

Anton, John P. 1968. “John Herman Randall, Jr.: A Biographical Sketch.” In J.P. Anton (ed.), Naturalism and Historical Understanding. Essays on the Philosophy of John Herman Randall, Jr., Albany sunY Press, 1968, vii-x.

Danto, Arthur C. 1952. "Acts and Histories." PhD dissertation, Dept. of Philosophy, Columbia University. CXo D236, Rare Book and Manuscript Library, Columbia University, New York.

Danto, Arthur C. 1953. "Mere Chronicle and History Proper." Journal of Philosophy 5o, 173-182.

Danto, Arthur C. 1954. “On Historical Questioning." Journal of Philosophy 51, 89-99.

Danto, Arthur C. 1955. “[Review] Social Science Research Council, Bulletin 64." Journal of Philosophy 52, 500-502.

Danto, Arthur C. 1956. "On Explanations in History." Philosophy of Science 23, 15-30.

Danto, Arthur C. 1958a. "On History and Theoretical Sentences." Studium Generale 11, 168-179.

Danto, Arthur C. 1958b. "[Review] W. Dray, Laws and Explanation in History." Ethics 68, 297-299

Danto, Arthur C. 1962. "Narrative Sentences." History and Theory 2, 146-179.

Danto, Arthur C. 1965a. Analytical Philosophy of History. Cambridge: Cambridge University Press. [Reprinted in toto in Danto 1985 b and 2007.] 
Danto, Arthur C. 1965b. Nietzsche as Philosopher. New York: Macmillan.

Danto, Arthur C. 1966. "Historical Understanding: The Problem of Other Minds." Journal of Philosophy 63, 566-577. Repr. in Danto 1985, 285-297.

Danto, Arthur C. 1967. "Naturalism." In Paul Edwards (ed.), The Encyclopedia of Philosophy, New York: Macmillan, Vol. 5, 448-45o.

Danto, Arthur C. 1968a. Analytical Philosophy of Knowledge. Cambridge: Cambridge University Press.

Danto, Arthur C. 1968b. "Reflections on Randall's Theory of Language." In J.P. Anton (ed.) Naturalism and Historical Understanding. Essays on the Philosophy of John Herman Randall Jr., Buffalo: sunY Press, 196-216.

Danto, Arthur C. 1973a. Analytical philosophy of Action. Cambridge: Cambridge University Press.

Danto, Arthur C. 1973b. "Historical Language and Historical Reality." Review of Metaphysics 27, 219-259. Repr. in Danto 1985b, 298-341.

Danto, Arthur C. 1982. "Narration and Knowledge." Philosophy and Literature 6, 17-32. Repr. in Danto 1985b, 342-363.

Danto, Arthur C. 1985a. "Introduction to the Morningside Edition." In Danto 1985b, ix-xiv.

Danto, Arthur C. 1985b, Narration and Knowledge. New York: Columbia University Press.

Danto, Arthur C. 1995. "The Decline and Fall of the Analytical Philosophy of History." In F.R. Ankersmith and H. Kellner (eds.), New Philosophy of History. Londom: Reaktion Books, 70-85. Repr. in Danto, The Body/Body Problem. Selected Essays. Berkeley: University of California Press, 164-183.

Danto, Arthur C. 1998a. "Arthur C. Danto [Interview]." In E. Domenska, Encounters. Philosophy of History After Postmodernism, Charlotteville: University of Virginia Press, $166-186$.

Danto, Arthur C. 1998b. "Art and Analysis. Interview with Peter Osborne." Radical Philosophy no. 9 o.

Danto, Arthur C. 2007a. "Response[s]." In Herwitz and Kelly 2007, 16-23 and 226-231.

Danto, Arthur C. 2007b. Narration and Knowledge. Second Enlarged Edition. New York: Columbia University Press.

Danto, Arthur C. 2013a. "Philosophical Autobiography." In R.W. Auxier and L.E. Hahn (eds.), The Philosophy of Arthur C. Danto. Chicago: Open Court, 3-70.

Danto, Arthur C. 2013b. "Hayden White and Me: Two Systems of Philosophy of History." In R. Doran (ed.), Philosophy of History After Hayden White, 109-117.

Danto, Arthur, and Morgenesser, Sidney (eds.). 196o. Philosophy of Science. New York: Meridian.

Davidson, Donald. 1963. "Actions, Reasons and Causes." Journal of Philosophy 6o, 68570o. Repr. in Davidson 1980, 3-20. 
Davidson, Donald. 1967. "Causal Relations." Journal of Philosophy 64, 691-703. Repr. in Davidson 1980, 149-162.

Davidson, Donald. 1970. "Mental Events." In L. Foster and J. W. Swanson (eds.), Experience and Theory, Amherst: University of Massachusetts Press, 79-101. Repr. in Davidson 1980, 207-224.

Davidson, Donald. 1973. "The Material Mind." In P. Suppes et al (eds.), Logic, Methodology, and Philosophy of Science, Amsterdam: North-Holland, 709-722 Repr. in Davidson 1980, 245-26o.

Davidson, Donald. 1974. "Psychology as Philosophy." In S.C. Brown (ed.), Philosophy of Psychology, London: Macmillan, 41-52, 6o-67. Repr. in Davidson 1980, 229-238.

Davidson, Donald. 1980. Essays on Actions and Events. Oxford: Clarendon Press.

Dewey, John. 1938. Logic: The Theory of Inquiry. New York: Holt, Rinehard and Winston. Repr. in Dewey, The Later Works Vol. 12, Carbondale: Southern Illinois University Press, 1984 .

Dilthey, Wilhelm. 1883. Einleitung in die Geisteswissenschaften. Leipzig. Repr. in Dilthey, Gesammelte Schriften, Band 1, Leipzig: Teubner, 1922.

Dilthey, Wilhelm. 1894. "Ideen über eine beschreibende und zergliedernde Psychologie." In Dilthey, Gesammelte Schriften, Band 5, Leipzig: Teubner, 1924, 139-240.

Dray, William. 1957. Laws and Explanations in History. Oxford: Oxford University Press. Earle, William James. 2018. "Early Danto." The Philosophical Forum 49, 541-558.

Goehr, Lydia. 2007a. "Afterwords: An Introduction to Arthur Danto's Philosophies of History and Art." History and Theory 40 (2007) 1-28.

Goehr, Lydia. 2007b. "Afterwords: An Introduction to Arthur Danto's Narration and Knowledge (including his Analytical Philosophy of History)." In Danto $2007 \mathrm{~b}$, xix-lvii.

Hanson, Russell Norwood. 1958. Patterns of Discovery. Cambridge: Cambridge University Press.

Hempel, C.G. 1942. "The Function of General Laws in History." Journal of Philosophy 39, 35-48. Repr. in H. Feigl, W. Sellars (eds.), Readings in Philosphical Analysis, New York, 1949, 459-473, and Hempel, Scientific Explanation. New York: Free Press, $1965,231-243$.

Hempel, C.G. 1952. "Typological Methods in the Natural and Social Sciences." In American Philosophical Association 1952. Repr. in Hempel 1965, 155-171.

Hempel, C.G., and Oppenheim, Paul. 1948. "Studies in the Logic of Explanation." Philosophy of Science 15, 135-175. Repr. in H. Feigl, M. Brodbeck (eds.), Readings in the Philosophy of Science, New York, 1953, 319-352. Repr. with a postscript in Hempel, Scientific Explanation. New York: Free Press, 1965, 245-296.

Herwitz, Daniel, and Kelly, Michael (eds.), 2007. Action, Art, History. Engagements with Arthur Danto. New York: Columbia University Press. 
Jarvis (Thomson), Judith. 1959. “[Review] G.E.M. Anscombe, Intention.” Journal of Philosophy 56, 31-41.

Kuhn, Thomas S. 1962. The Structure of Scientific Revolutions. Chicago: University of Chicago Press.

Malcolm, Norman. 1950. “The Verificationist Argument.” In M. Black (ed.), Philosophical Analysis, Ithaca: Cornell University Press, 244-298.

Mandelbaum, Maurice. 1938. The Problem of Historical Knowledge. New York: Liveright Publishing.

Megill, Allan. 20o9. "The Rhetorical Dialectic of Hayden White." In F. Ankersmit, E. Domanska, H. Kellner (eds.), Re-Figuring Hayden White, Stanford: Stanford University Press, 190-215.

Mink, Louis O. 1968. "Philosophical Analysis and Historical Understanding." Review of Metaphysics 11, 667-698. Repr. in Mink 1987, 118-146.

Nagel, Ernest. 1952. "Problems of Concept and Theory Formation in the Social Sciences." In American Philosophical Association 1952. Repr. in M. Nathanson (ed.), Philosophy of the Social Sciences: A Reader, New York: Random House, 1963, 189-209. Nagel, Ernest. 1961. The Structure of Science. New York: Harcourt, Brace and World.

Parsons, Talcott. 1949. The Structure of Social Action. Glencoe, Ill.: The Free Press.

Roth, Paul A. 2017. "Philosophy of History." In L. Macintyre and A. Rosenberg (eds.), The Routledge Companion to Philosophy of Social Science, London: Routledge, 397-407.

Uebel, Thomas. 2017. "Philosophy of History and History of Philosophy of Science." HOPOS $7,1-3$ O.

Walsh, W.H. 1951. An Introduction to Philosophy of History, London: Hutchinson, 1951. 2nd rev. ed Philosophy of History, 1958. 